\title{
KORELASI SELF EFFICACY TERHADAP KEMAMPUAN PENALARAN MATEMATIS MAHASISWA SEMESTER PENDEK MATA KULIAHTRIGONOMETRI UNRIKA
}

\author{
Nailul Himmi \\ Program Studi Pendidikan Matematika, Fakultas Keguruan dan Ilmu Pendidikan \\ Universitas Riau Kepulauan, Kepulauan Riau, Indonesi \\ e-mail: nailulhimmi@fkip.unrika.ac.id
}

\begin{abstract}
Abstrak. Penelitian ini bertujuan untuk mengetahui hubungan antara self efficacy terhadap kemampuan penalaran matematis mahasiswa semester pendek pada mata kuliah trigonometri T.A 2016/2017. Jenis penelitan korelasional dengan populasi sebanyak 35 orang dan teknik pengambilan sampel adalah sampeling jenuh. Instrument penelitian berupa Angket sebanyak 35 pertanyaan dan essay test sebanyak 5 pertanyaan. Uji validitas menggunakan person product moment dengan nilai uji reliabilitas angket 0.818 dan test 0.717 . Teknik analisis data menggunakan uji spearman's rho di kerenakan data tidak berdistribusi normal dengan signifikan $\alpha=5 \%$. Hasil penelitian diperoleh tidak terdapat hubungan yang signifikan antara self efficacy dan penalaran matematis mahasiswa semester pendek matakuliah trigonometri UNRIKA T.A 2016/2017 (sig 0.644>0.05). Dengan besar nilai korelasi 0.081 yang menunjukkan hubungan yang sangat lemah.
\end{abstract}

Kata Kunci: Self efficacy, kemampuan penalaran, Trigonometri

Abstract. This study aims to determine the relationship between self efficacy to the mathematical reasoning of students short semester on trigonometry T.A 2016/2017. This research is correlational with population as much 35 people and sampling technique is saturated sampling. Instrument research in the form of Questionnaire as many as 35 questions and essay test as many as 5 questions. Validity test using person product moment with test reliability test value 0.818 and test 0.717 . The technique of data analysis using spearman's rho test in the data knob is not normally distributed with significant $\alpha=5 \%$. The result of the research shows that there is no significant relationship between self efficacy and mathematical reasoning of short semester students trigonometric course UNRIKA T.A 2016/2017 ( $\operatorname{sig} 0.644>0.05$ ). With a large correlation value of 0.081 indicating a very weak relationship.

Keywords: self efficacy, mathematical reasoning, Trigonometry

\section{Pendahuluan}

Universitas merupakan suatu institusi pendidikan tinggi dan penelitian, yang memberikan gelar akademik dalam berbagai bidang. Sebuah universitas menyediakan pendidikan sarjana dan pascasarjana. Kata universitas berasal dari bahsa latin universitas magistrorum et scholarium yang berarti "komunitas guru dan akademis". Berdasarkan Undang-undang Republik Indonesia No 20 tahun 2003 tentang Sistem Pendidikan Nasional, Universitas dalam pendidikan di Indonesia merupakan salah satu bentuk perguruan tinggi selain akademi, institute, politeknik dan sekolah tinggi. Universitas terdiri atas sejumlah fakultas yang menyelenggarakan pendidikan akademik pada sejumlah pengetahuan, teknologi yang memenuhi syarat penyelenggarakan pendidikan profesi. 
UNRIKA (Universitas Riau Kepulauan) merupakan salah satu universitas di kota Batam sejak 12 Desember 1992 (Unrika: 2017). yang memberikan kepada lulusan program pendidikan sarjana. Untuk mendapatkan felar sarjana, secara normative dibutuhkan waktu selama 4(empat) sampai 6(enam) tahun. Sistem perkuliahan berupa pembelajaran semester ganjil dan semester genap. Dengan jumlah tatap muka untuk setiap matakuliah sebanyak 16 kali termasuk UTS dan UAS. Diantara semester genap dan semester ganjil diadakan semester pendek dengan jumlah pertemuan tatap muka sama. Hal yang melatar belakangi semester pendek adalah ada beberapa mahasiswa yang memiliki nilai yang kurang untuk mencapai kelulusan sebagai syarat yudisium (Zamhari: 2017). Pada program studi pendidikan matematika mengadakan semester pendek bagi mahasiswa yang ingin melengkapi sks akademik atau memperbaiki nilai yang sudah diperoleh pada semester sebelumnya. Salah satu matakuliah yang mengikuti program semester pendek pada T.A 2016/2017 adalah matakuliah Trigonometri. Pada matakuliah trigonometri mahasiswa kurang mampu melakukan pembuktian-pembuktian antara rumus trigonometri. Kebanyakan dari mahasiswa tidak percaya diri dalam menggunakan rumus-rumus mana yang sesuai dengan pembuktian trigonometri tersebut. Karena dalam pembelajaran trigonometri memerlukan kemampuan penalaran yang baik serta memiliki rasa kepercayaan diri yang tinggi untuk membuktikannya. Untuk itu, penelitian ini bertujuan untuk mengetahui korelasi self efficacy dan kemampuan penalaran matematis mahasiswa semester pendek mata kuliah trigonometri T.A 2016/2017.

Trigonometri berasal dari bahasa yunani trigon $=$ tiga sudut dan metro $=$ mengukur. Trigonometri merupakan salah satu cabang matematika yang berhadapan dengan sudut segitiga. Selain itu trigonometri memiliki hubungan dengan geometi. Konsep dasar dari trigonometri adalah kesebangunan segitiga siku-siku. Sisi-sisi yang bersesuaian pada dua bangun datar yang sebangun memiliki perbandingan yang sama. Pada geometri euclid, jika masing-masing sudut segitigamemiliki besar yang sama, maka kedua segitiga itu pasti sebangun (Boyer, Carl B.: 1991). Hal ini adalah dasar untuk perbandingan trigonometri sudut lancip yang kemudian dikembangkan menjadi konsep sudut-sudut non lancip.

Ada banyak aplikasi trigonomeri, terutama adalah teknik triangulasi yang digunakan dalam astronomi untuk menghitung jarak ke bintang-bintang terdekat. Dalam geogerafi untuk menghitung antara titik tertentu dan dalam sistem nasvigasi satelit. Bidang lainnya yang menggunkan trigonometri termasuk astronomi, teori musik, akustik, optik, analisis pasar finansial, elektronik, teori probabilitas, statistika, biologi, pencitraan medis, farmasi, kimia, metorologi, oseonografi, berbagai cabang ilmu fisika, dan lainnya (Wikipedia: 2017).

Adapun identitas dasar dari trigonometri adalah berasal dari segitiga siku-siku dengan titik-titik sudut $A, B$ dan $C$ sisi-sisi yang berhadapan dengan sudut tersebut adalah $a, b$ dan hipotenusa $c$ serta sudut $\theta$ di $\mathrm{B}$, seperti gambar dibawah ini. 


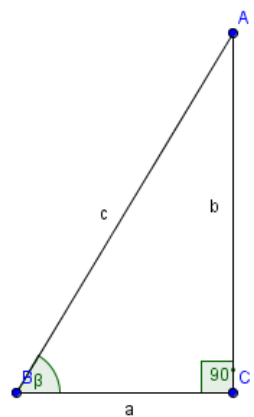

Gambar 1. Segitiga siku-siku

Dari gambar diatas diperoleh $a^{2}+b^{2}=c^{2}$, dengan membagikan kedua sisi dengan $c^{2}$ akan dihasilkan:

$$
\left(\frac{a}{c}\right)^{2}+\left(\frac{b}{c}\right)^{2}=1
$$

Karena $\frac{a}{c}=\cos \theta$ dan $\frac{b}{c}=\sin \theta$, maka persamaan ini dapat dituliskan sebagai berikut, yang merupakan identitas dasar trigonometri (Stroud, K.A: 2003)

$$
\begin{gathered}
\cos ^{2} \theta+\sin ^{2} \theta=1 \\
1+\tan ^{2} A=\frac{1}{\cos ^{2} A}=\operatorname{Sec}^{2} A \\
1+\operatorname{Cot}^{2} A=\frac{1}{\operatorname{Sin}^{2} A}=\operatorname{Csc}^{2} A
\end{gathered}
$$

Adapun persamaan trigonometri lanjutan sebagai berikut:

$$
\begin{gathered}
\operatorname{Sin}(\mathrm{A}+\mathrm{B})=\operatorname{Sin} A \cdot \operatorname{Cos} B+\operatorname{Cos} A \cdot \operatorname{Sin} B \\
\operatorname{Sin}(\mathrm{A}-\mathrm{B})=\operatorname{Sin} A \cdot \operatorname{Cos} B-\operatorname{Cos} A \cdot \operatorname{Sin} B \\
\operatorname{Cos}(\mathrm{A}+\mathrm{B})=\operatorname{Cos} A \cdot \operatorname{Cos} B-\operatorname{Sin} A \cdot \operatorname{Sin} B \\
\operatorname{Cos}(\mathrm{A}-\mathrm{B})=\operatorname{Cos} A \cdot \operatorname{Cos} B+\operatorname{Sin} A \cdot \operatorname{Sin} B \\
\operatorname{Tan}(\mathrm{A}+\mathrm{B})=\frac{\operatorname{Tan} A+\operatorname{Tan} B}{1-\operatorname{Tan} A \cdot \operatorname{Tan} B} \\
\operatorname{Tan}(\mathrm{A}-\mathrm{B})=\frac{\operatorname{Tan} A-\operatorname{Tan} B}{1+\operatorname{Tan} A \cdot \operatorname{Tan} B} \\
2 \operatorname{Sin} A \cdot \operatorname{Cos} B=\operatorname{Sin}(A+B)+\operatorname{Sin}(A-B) \\
2 \operatorname{Cos} A \cdot \operatorname{Sin} B=\operatorname{Sin}(A+B)-\operatorname{Sin}(A-B) \\
2 \operatorname{Cos} A \cdot \operatorname{Cos} B=\operatorname{Cos}(A+B)+\operatorname{Cos}(A-B) \\
2 \operatorname{Sin} A \cdot \operatorname{Sin} B=-\operatorname{Cos}(A+B)+\operatorname{Cos}(A-B) \\
\operatorname{Sin} A+\operatorname{Sin} B=2 \operatorname{Sin} \frac{1}{2}(A+B) \cdot \operatorname{Cos} \frac{1}{2}(A-B) \\
\operatorname{Sin} A-\operatorname{Sin} B=2 \operatorname{Cos} \frac{1}{2}(A+B) \cdot \operatorname{Sin} \frac{1}{2}(A-B) . \\
\operatorname{Cos} A+\operatorname{Cos} B=2 \operatorname{Cos} \frac{1}{2}(A+B) \cdot \operatorname{Cos} \frac{1}{2}(A-B) \\
\operatorname{Cos} A-\operatorname{Cos} B=-2 \operatorname{Sin} \frac{1}{2}(A+B) \cdot \operatorname{Sin} \frac{1}{2}(A-B) \\
\operatorname{Sin} 2 A=2 \operatorname{Sin} A \cdot \operatorname{Cos} A
\end{gathered}
$$$$
\operatorname{Cos} 2 A=\operatorname{Cos}^{2} A-\operatorname{Sin}^{2} A=1-2 \operatorname{Sin}^{2} A=2 \operatorname{Cos}^{2} A-1
$$ 


$$
\operatorname{Tan} 2 A=\frac{2 \operatorname{Tan} A}{1-\operatorname{Tan}^{2} A}=\frac{2 \operatorname{Cot} A}{\operatorname{Cot}^{2} A-1}=\frac{2}{\operatorname{Cot} A-\operatorname{Tan} A}
$$

Rumus-rumus diatass merupakan rumus-rumus dasar untuk membuktikan persamaan trigonometri yang diberikan. Dalam pembuktiannya, memerlukan kemampuan berfikir secara nalar dan logis. Menurut Eccles "A proof of mathematical statement is a logical argument which establishes the truth of the statment. the steps of the logical argument are provided by implications". Dimana membukti pernyataan matematis menggunakan argumen yang logis untuk menetapkan kebenaran statemen menggunakan langkah-langkah implikasi. Eccles, PJ. (2007). Dengan kata lain, untuk dapat membuktikan persamaan tersebut memerlukan penalaran matematis yang baik.

Penaralan merupakan kompetensi yang termuat dalam matematika, seperti yang dinyatakan De Lange (dalam Hasratuddin, 2015:91) bahwa kompotensi atau kemampuan yang termuat dalam Matematika adalah berpikir dan bernalar secara matematis (Mathematical thinking and reasoning), berargumentasi secara matematis (mathematical argumentation), berkomunikasi secara sistematis (mathematical communication), pemodelan (modelling), penyusunan dan pemecahan masalah (problem posing and solving), representasi (representation), symbol (symbol), dan sarana teknologi (tools and technology).

Piaget (dalam Hasratuddin, 2015:91) Mengatakan bahwa adapun ciri-ciri penalaran sebagai berikut.

1. Ciri pertama adalah adanya suatu pola berpikir yang secara luas dapat di sebut logika, dan tiap penalaran mempunyai logika tersendiri atau juga dapat disimpulkan bahwa kegiatan penalaran merupakan suatu kegiatan berpikir logis, dimana berpikir logis disini harus dapat diartikan sebagai kegiatan berpikir menurut suatu pola tertentu.

2. Ciri yang kedua dari penalaran adalah sifat analitik dari proses berpikirnya. Penalaran merupakan suatu kegiatan berpikir yang menyandarkan diri kepada suatu analisis dan kerangka berpikir dalam suatu analisis tersebut adalah logika penalaran yang bersangkutan.

Ciri-ciri penalaran yang di ungkapkan di atas pada intinya merupakan suatu proses berpikir dengan cara tertentu yang menghasilkan kesimpulan berupa pengetahuan. Cara tertentu yang di maksud adalah logika atau cara yang masuk akal. Penalaran matematika ini ditandai dengan beberapa indikator sebagai berikut; (1) Mampu mengajukan dugaan (Conjucture), (2) Memberikan alasan atau bukti terhadap kebenaran suatu pernyataan, (3) Menarik kesimpulan dari suatu pernyataan, (4) Memeriksa keahlian argumen, (5) Menemukan pola pada suatu gejala matematis dan (6) Memberikan alternatif bagi suatu argument.

Self efficacy mempengaruhi pengambilan keputusan dan tindakan yang akan dilakukannya (Himmi, 2016). Hal ini perkuat oleh Warwick (2008: 32) bahwa self efficacy merupakan bagian dari kognisi seseorang yang mempengaruhi pengambilan keputusan sesseorang untuk mengorganisasikan dan menyusun tindakan untuk mencapai hasil yang diinginkan. Menurut Bandura (1977: 195) untuk memperkuat self efficacy tersebut, dipengaruhi oleh empat sumber prinsip pembentuk (indikator) self efficacy yaitu: (1) pencapaian kinerja (performance accomplishments) merupakan sumber pengharapan yang utama karena didasarkan pada pengalaman individu ketika berhasil mengerjakan sesuatu hal dengan baik. (2) Pengalaman orang lain (vicarious experience) adalah pengalaman yang didapat ketika individu melihat keberhasilan orang lain dalam mengerjakan tugas dengan 
baik. Individu yang melihat atau mengamati orang lain yang mencapai keberhasilan dapat menimbulkan persepsi self efficacy-nya. (3) Persuasi verbal (verbal persuasion) digunakan untuk memberi keyakinan kepada seseorang bahwa ia memiliki suatu kemampuan yang memadai untuk mencapai apa yang ia inginkan. (4) Dorongan emosional (emotional arousal) adalah muncul dan naiknya emosi seseorang ketika individu berada dalam situasi yang tertekan.

Bandura (1999: 28) mengemukakan bahwa self efficacy merupakan dasar dari pengambilan keputusan seseorang, seperti: (1) Mempengaruhi pengambilan keputusannya, dan mempengaruhi tindakan yang akan dilakukannya. Seseorang cenderung akan menjalankan sesuatu apabila ia merasa kompeten dan percaya diri dan akan menghidarinya apabila tidak; (2) Membantu seberapa jauh upaya ia bertindak dalam suatu aktivitas, berapa lama ia bertahan apabila mendapat masalah, dan seberapa fleksibel dalam suatu situasi yang kurang menguntungkan baginya. Makin besar self efficacy seseorang makin besar upaya, ketekunan dan fleksibilitasnya; dan (3) Mempengaruhi pola pikir dan reaksi emosionalnya. Seseorang yang mempunyai self efficacy yang rendah mudah menyerah dalam menghadapi masalah dan cenderung menjadi stress, depresi dan mempunyai suatu visi yang sempit tentang apa yang terbaik untuk menyelesaikan masalah. Sedangkan self efficacy yang tinggi akan membantu seseorang dalam menciptakan suatu perasaan tenang dalam menghadapi masalah atau aktivitas yang sukar.

\section{Metode Penelitian}

Jenis penelitian yang digunakan dalam penelitian ini adalah korelasional. Dengan variabel bebas (X) adalah Self efficacy dan variable terikat (Y) adalah penalaran matematis. Penelitian ini dilakukan di UNRIKA, pada 17 Juli 2017 - 07 Agustus 2017. Adapun populasi adalah mahasiswa yang mengikuti semester pendek matakuliah trigonometri yang berjumlah 35 orang dan teknik pengambilan sampel menggunakan sampeling jenuh. Instrument kemapuan penalaran matematis penelitian berupa essay test sebanyak 5soal. Indikator kemampuan penalaran matematis yaituL(1) Mampu mengajukan dugaan (Conjucture), (2) Memberikan alasan atau bukti terhadap kebenaran suatu pernyataan, (3) Menarik kesimpulan dari suatu pernyataan, (4) Memeriksa keahlian argumen, (5) Menemukan pola pada suatu gejala matematis. Dan angket self efficacy sebanyak 35 soal dengan indikator (1) pencapaian kinerja, (2) pengalaman orang lain, (3) persuasi verbal dan (4) dorongan emosional.

Seluruh instrumen yang digunakan dinyatakan valid, dengan uji konstruk instrumen menggunakan rumus person product moment (Irianto:2007). Nilai reliabilitas angket (0.818) dan essay test (0.715) dengan menggunakan rumus reliabilitas alpha cronbach dan dinyatakn reliable. Uji normalitas data menggunakan Kolmogorov-smirnov, dan uji hipotesis menggunakan spearman's rho. Seluruh uji pada penelitian ini berbantuan software SPSS 21 . Dimana jika Sig $\geq 0.05$ maka Ho diterima dan jika sig $<0.05$ maka Ho diterima. Untuk melihat nilai $\mathrm{r}$ akan dikonsultasikan dengan menggunakan tabel interpretasi $\mathrm{r}$ sebagai berikut: 
Tabel 1. Interpretasi $\mathrm{r}$

\begin{tabular}{cc}
\hline Interval Koefisien & Tingkat Hubungan \\
\hline $0.80-1.00$ & Sangat kuat \\
$0.60-0.79$ & Kuat \\
$0.40-0.59$ & Cukup kuat \\
$0.20-0.39$ & Rendah \\
$0.00-0.19$ & Sangat rendah \\
\hline
\end{tabular}

(Sanjaya: 2013)

\section{Hasil Penelitan dan Pembahasan}

Adapun hasil deskripsi dari pemberian angket (35 soal( dan essay test (5 soal) kepada masiswa yang mengikuti semester pendek trigonometrsi sebanyak 35 mahasiswa sebagai tabel 2 berikut:

Tabel 2. Deskripsi Hasil Penelitian

Descriptive Statistics

\begin{tabular}{|l|r|r|r|r|r|r|r|}
\hline & N & Minimum & Maximum & Sum & Mean & Std. Deviation & Variance \\
\hline Penalaran & 35 & 55.71 & 83.57 & 2489.27 & 71.1220 & 6.38756 & 40.801 \\
S.Efficacy & 35 & 25.00 & 75.00 & 1768.00 & 50.5143 & 11.23904 & 126.316 \\
Valid N (listwise) & 35 & & & & & & \\
\hline
\end{tabular}

Data yang dianalisis, merupakan data yang sudah dikonfersikan keskala 100, sehingga diperoleh rerata penalaran sebesar 71.12 dan rerata self efficacy sebesar 50.51. Selanjutnya dilakukan uji normalitas data yang disajikan pada tabel 3:

Tabel 3. Uji Normalitas

Tests of Normality

\begin{tabular}{|l|r|r|r|r|r|r|}
\hline & \multicolumn{3}{|c|}{ Kolmogorov-Smirnov $^{\mathrm{a}}$} & \multicolumn{3}{c|}{ Shapiro-Wilk } \\
\cline { 2 - 7 } & Statistic & \multicolumn{1}{|c|}{ Df } & \multicolumn{1}{c|}{ Sig. } & Statistic & \multicolumn{1}{c|}{ Df } & \multicolumn{1}{c|}{ Sig. } \\
\hline S.Efficacy & .071 & 35 & .200 & .983 & 35 & .863 \\
Penalaran & .167 & 35 & .014 & .927 & 35 & .023 \\
\hline
\end{tabular}

*. This is a lower bound of the true significance.

a. Lilliefors Significance Correction

Dari hasil uji normalitas, diperoleh bahwa kemampuan penalaran matematis mahasiswa adalah tidak normal dengan nilai signifikan (0.014) < P.sig (0.05), dan self efficacy mahasiswa tersebut normal dengan nilai signifikan $0.200>$ P.sig (0.05). Sehingga, dalam mengetahui hubungan antar variable menggunakan uji spearman's rho. Adapun untuk uji hipotesis sebagai berikut:

Ho: tidak terdapat hubungan yang signifikan antara self efficacy dan penalaran matematis mahasiswa semester pendek mata kuliah trigonometri UNRIKA T.A 2016/2017

Ha: terdapat hubungan yang signifikan antara self efficacy dan penalaran matematis mahasiswa semester pendek matakuliah trigonometri UNRIKA T.A 2016/2017

Adapun hasil uji spearman's rho seperti tabel 4. 
Tabel 4. Uji Korelasi

\section{Correlations}

\begin{tabular}{|lll|r|r|}
\hline & & Penalaran & S.Efficacy \\
\hline \multirow{4}{*}{ Spearman's rho } & \multirow{3}{*}{ Penalaran } & Correlation Coefficient & 1.000 & .081 \\
& & Sig. (2-tailed) &. & .644 \\
& & $\mathrm{~N}$ & 35 & 35 \\
& & Correlation Coefficient & .081 & 1.000 \\
& \multirow{2}{*}{ S.Efficacy } & Sig. (2-tailed) & .644 &. \\
& & $\mathrm{~N}$ & 35 & 35 \\
\hline
\end{tabular}

Dengan memperhatikan nilai sig(0.81) $>$ P. sig(0.05) maka Ho diterima. Dimana tidak terdapat hubungan yang signifikan antara self efficacy dan penalaran matematis mahasiswa semester pendek matakuliah trigonometri UNRIKA T.A 2016/2017. Adapun melihat interpretasi hubungan antara penalaran dan self efficacy sebesar 0.081 yang menunjukkan hubungan yang sangat rendah.

Dari uji hipotesis tersebut, dapat dilihat bahwa tidak terdapat hubungan antara self efficacy dan penalaran matematis mahasiswa yang mengikuti perkuliahan semester pendek matakuliah trigonometri. Hal ini dilihat bahwa penalaran dalam membuktikan rumus-rumus yang berkaitan dengan trigonometri tidak memerlukan self efficacy, melainkan membutuhkan kemampuan-kemampuan berfikir untuk menyelesaikannya, seperti logika dalam berfikirnya untuk menaik kesimpulan berdasarkan alasan yang valid. Hal ini sesuai dengan penyataan Shadiq (dalam Hidayati \& Widodo, 2015: 132) penalaran merupakan kegiatan, kegiatan atau aktivitas berpikir untuk menarik suatu kesimpulan atau membuat suatu pernyataan baru berdasarkan pada beberapa pernyataan yang diketahui benar ataupun yang di anggap benar atau di sebut Premis. Meskipun Russel (dalam Hasratuddin, 2015:94) menyatakan bahwa penalaran adalah pusat belajar matematika dimana penalaran digunakan sebagai alat untuk mengabstraksi objek matematika dan menjadi landasan dalam pembentukan karakter seseorang. Dimana salah satu karakter seseorang tersebut adalah self efficacy. Namun, hubungan antara self efficacy dan penalaran itu sendiri sangat lemah yaitu hanya sebesar 0.081 .

Self Efficacy adalah penilaian seseorang tentang kemapuannya sendiri untuk menjalankan prilaku tertentu atau mencapai tujuan tertentu (Ormrod: 2008). Meskipun Warwick (Himmi, 2016) menyatakan bahwa self efficacy merupakan bagian dari kognisi seseorang yang mempengaruhi pengambilan keputusan seseorang untuk mengorganisasikan dan menyusun tindakan untuk mencapai hasil yang diinginkan. Namun keinginan ini bukanlah kemampuan penalaran matematis mahasiswa. Seperti pernyataan Bandura (1977) Self Efficacy tidak berkaitan langsung dengan kecakapan yang dimiliki individu, melainkan pada penilaian diri tentang apa yang dapat dilakukan, tanpa terkait dengan kecakapan yang dimiliki. Jadi kemampuan penalaran matematis siswa, tidak dipengaruhi langsung oleh self efficacy melainnya dipengaruhi faktor lainnya. Berupa kemampuan berfikir lainnya yang tidak dibahas dalam penelitian ini. 


\section{Kesimpulan dan Saran}

Adapun kesimpulan dalam penelitian ini Tidak terdapat hubungan yang signifikan self efficacy dan penalaran matematis mahasiswa semester pendek di UNRIKA T.A 2016/2017. Dengan besar nilai korelasi 0.081 yang menunjukkan hubungan yang sangat lemah. Dan saran pada penelitian ini agar dilakukan penelitian lanjutan mengenai variable-variable lainnya untuk meningkatkan kemampuan penalaran matematis mahasiswa.

\section{Daftar Pustaka}

Bandura. 1977. Self efficacy: Toward a Unifying Theory of Behavioral Change. Psychological Review, Vol 84 No 1: 191-215

1999. Social Cognitive Theory: An Agentic Perspective. Asian Journal of Social Psychollogy, Vol 2: 21-41.

Boyer, Carl B. 1991. A History of Mathematics (Second Edition ed.). John Wiley \& Sons, Inc. ISBN 0-471-54397-7.

Eccles, PJ. (2007). An Introduction to Mathematical Reasioning Number, sets and functions. Newyork: Cambrige University.Hasratuddin. 2015. Mengapa Harus Belajar Matematika. Medan: Perdana Publishing

Himmi, N. 2016. Perbedaan Self Efficacy Matematis Siswa Antara Pembelajaran Berbasis Masalah Berbantuan Geogebra dan Autograph di MAN 1 Medan. Pythagoras, 5(2), $165-171$. Retrieved from http://journal.unrika.ac.id/index.php/jurnalphythagoras/article/view/469/353

Hidayati \& Widodo. 2015. Proses Penalaran Matematis Siswa Dalam Memecahkan Masalah Matematika Pada Materi Pokok Tiga Dimensi Tiga Berdasarkan Kemampuan Siswa di SMA Negeri 5 Kediri. Jurnal Math Educator Nusantara. Vol 1 No.02.

Irianto,A. 2007. Statistik Konsep dasar, aplikasi dan pengembangannya. Jakarta: Kencana Prenda Media Group

Ormrod, JE. 2008. Psikologi Pendidikan Jilid I. Jakarta: Erlangga

Sanjaya, W. 2013. Penelitian Pendidikan Jenis, Metode Dan Prosedur. Jakarta: Kencana.

Stroud, K.A: 2003, Matematika teknik jilid I, Jakarta: Erlangga

Unrika. 2017. Sejarah Unrika. Online: www.unrika.ac.id/sejarah/ . Diakses tanggal 1 Agustus 2017

Warwick, J. 2008. Mathematical self efficacy and student engagement in the mathematics classroom. MSOR Connection, Vol 8 No 3: 31-37.

Wikipedia. 2017. Trigonometri. Online:https://id.wikipedia.org/wiki/Trigonometri. Diakses tanggal 1 Agustus 2017

Zamhari: 2017. Pengertian Semester Pendek . Online: http://www.academicindonesia.com/pengertian-kuliah-semester-pendek/. Diakses tanggal 1 Agustus 2017 